\title{
ANALÝZA EFEKTÍVNOSTI SPRIAHOVACÍCH LÍŠT V DREVOBETÓNOVÝCH KONŠTRUKCIÁCH
}

\author{
ANALYSIS OF EFFICIENCY OF PERFORATED STEEL STRIPS IN \\ TIMBER-CONCRETE STRUCTURES
}

\author{
Adam Petrík ${ }^{*}, 1$ \\ "adam.petrik@stuba.sk \\ ${ }^{1}$ Slovenská technická univerzita v Bratislave, Stavebná fakulta, Katedra kovových a drevených konštrukcií, Radlinského 11, 81005 \\ Bratislava, Slovenská republika
}

\begin{abstract}
Abstrakt
Spriahovacie lišty ako alternatívny spôsob spriahovania ocel'obetónových konštrukcií našli uplatnenie najmä v mostnom stavitel'stve, no stále častejšie sa vyskytujú aj v objektoch pozemných stavieb, kde je potrebné prekonávat' vel'ké rozpätia. Použitie spriahovacích líšt v drevobetónových konštrukciách vzhl'adom na absenciu komplexných poznatkov nedosahuje úrovne iných druhov spriahovacích prostriedkov. Numerickými simuláciami je možné analyzovat' správanie sa takýchto konštrukcií, ako aj sledovat' napätostné parametre jednotlivých prvkov. Na základe výsledkov z týchto simulácií je možné zhodnotit' potenciál takýchto konštrukcií, ako aj d’alšie smery výskumu drevobetónových konštrukcií so spriahovacími lištami.
\end{abstract}

\section{Klíčová slova}

Drevobetónové konštrukcie, spriahovacie lišty, numerické simulácie

\begin{abstract}
Perforated steel strips as an alternative coupling method of steel-concrete structures have found application mainly in bridge construction, but they are also increasingly used in building structures, where it is necessary to overcome large spans. Due to the absence of complex knowledge, the usage of perforated steel strips in timber-concrete structures does have not reached the level of other types of coupling methods. Numerical simulations can be used to analyse the behaviour of such structures, as well as monitor the stress parameters of individual elements. Based on the results of these simulations, it is possible to evaluate the potential of such structures, as well as other directions of research of timber-concrete structures with perforated steel strips.
\end{abstract}

\section{Key words}

Timber-concrete structures, perforated steel strips, numerical simulations

\section{1 ÚVOD}

Využívanie spriahovacích líšt ako spriahovacích prostriedkov betónu a ocele kontinuálne zvyšuje najmä v oblasti mostného stavitel'stva, kde majú takéto konštrukcie vd'aka kombinácii dobrých statických a únavových vlastností majú predpoklady spol'ahlivo fungovat' počas celej doby životnosti. Ocel'obetónové prvky spriahnuté spriahovacími lištami sa však začínajú vyskytovat' aj v objektoch pozemného stavitel'stva, kde je možné vd'aka týmto prvkom jednoduchšie prekonávat' vel'ké rozpätia medzi podpernými konštrukciami a využivat' výhodné únavové vlastnosti - jedná sa najmä o objekty parkovacích domov [1].

Výskum širšieho využitia spriahovacích líšt v drevobetónových konštrukciách však stále absentuje, pričom jednou z výnimiek je použitie tenkých dierovaných líšt HBV® firmy TiComTec [2]. Používanie aj iných druhov spriahovacích líšt, ktoré by prispelo k zatraktívneniu využívania týchto druhov spriahnutých konštrukcií, zatial' nebolo skúmané.

Vzhl'adom na absenciu základných poznatkov o možnom správaní spriahnutých drevobetónových konštrukcií s použitými spriahovacími lištami, je vhodné využit' numerické simulácie na analýzu napätostných a deformačných parametrov týchto konštrukcií s ciel'om získat' informácie o správaní sa jednotlivých častí týchto konštrukcií pod vplyvom zvyšujúceho sa zat’aženia a tým vyhodnotit' prípadný potenciál týchto konštrukčných prvkov v budovách. 
Príspevok sa zaoberá možnost’ou využitia numerických simulácií pri analýze spriahnutých drevobetónových nosníkov prostredníctvom spriahovacích líšt, ako aj vplyv zat’aženia, materiálových vlastností a materiálových modelov jednotlivých prvkov modelov na statické a deformačné parametre konštrukcie.

\section{SÚČASNÝ STAV PROBLEMATIKY}

Spriahovacie lišty je možné po takmer štyridsiatich rokoch výskumu v oblasti ocel'obetónových konštrukcií považovat' za bezpečnú a spol'ahlivú alternatívu k bežne použivaným spriahovacím prostriedkom, najmä tŕňom s hlavou, pričom často predstavujú alternatívu s vyššou únosnost'ou a lepšími únavovými vlastnost'ami. Pre niektoré typy spriahovacích líšt ako typ MCL či PZ boli na základe realizovaného výskumu vydané návrhové postupy a technické schválenie (Allgemeine bauaufsichtliche Zulassung Z-26.4-56 - Stahlverbundträger mit Verbunddübelleisten in Klothoiden- und Puzzleform) [3]. Jedná sa však len o lišty používané v ocel'obetónových konštrukciách.

V prípade drevobetónových konštrukcií je možné považovat' za spriahovacie lišty tenké perforované lišty HBV® firmy TiComTec [2], ktorých výskum bol ukončený vydaním technického schválenia (Allgemeine bauaufsichtliche Zulassung Z-9.1-557 - HBV-Schubverbinder aus Streckmetall und vorgefertigte Bauteile mit eingeklebten; HBV-Schubverbindern für ein Holz-Beton-Verbundsystem) [4]. Tieto lišty sú vlepované do vyfrézovaných drážok v drevených prvkoch (nosníkoch, CLT doskách). Následne sa uloží betonárska výstuž a dôjde k betonáži (obr. 1). Výhodou tohoto systému pre obytné budovy je možnost' viest' betónovou vrstvou elektroinštaláciu, rovnako aj ju vybavit’ elektrickým podlahovým vykurovaním.
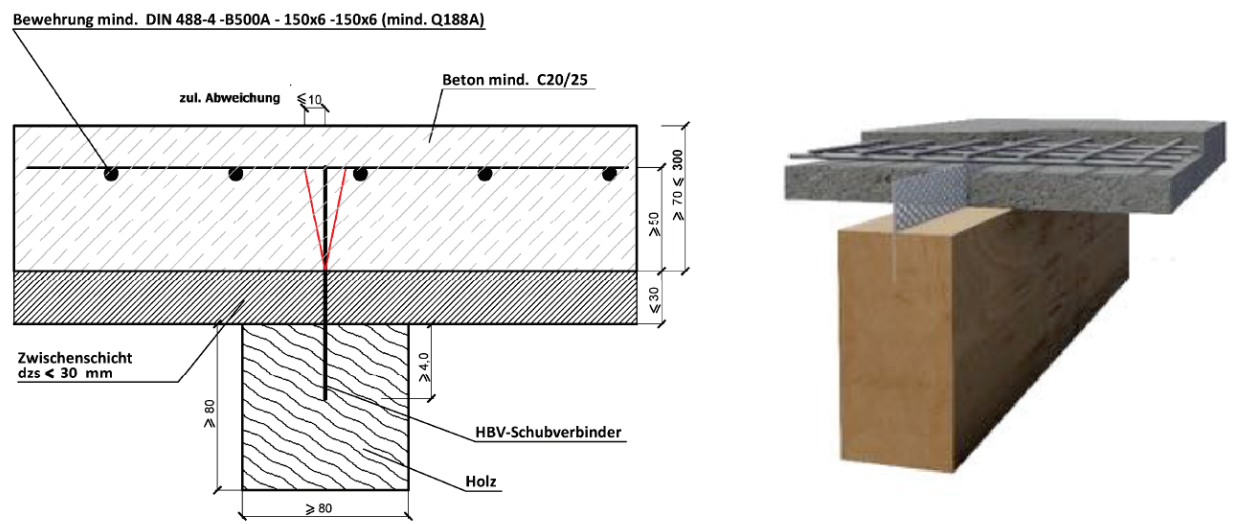

Obr. 1 Priečny rez drevobetónových nosníkov s lištami HBV® firmy TiComTec [4].

Podobnými perforovanými ocel'ovými lištami sa zaoberal aj výskum na Univerzite v A Coruña (Španielsko) [5]. Tie kombinovali aj s účinkom doplnkovej priečnej a pozdĺžnej betonárskej výstuže (obr.2). Výskum sa zameral na efektivitu prenosu pozdížnej šmykovej sily prostredníctvom spriahovacej lišty medzi drevenou a betónovou čast'ou prierezu ako laboratórnymi experimentami, tak aj numerickými simuláciami s ciel'om definovat' tuhostné parametre spojenia, ako aj verifikovat' numerický model na skúmanie spriahnutia drevobetónových konštrukcií.
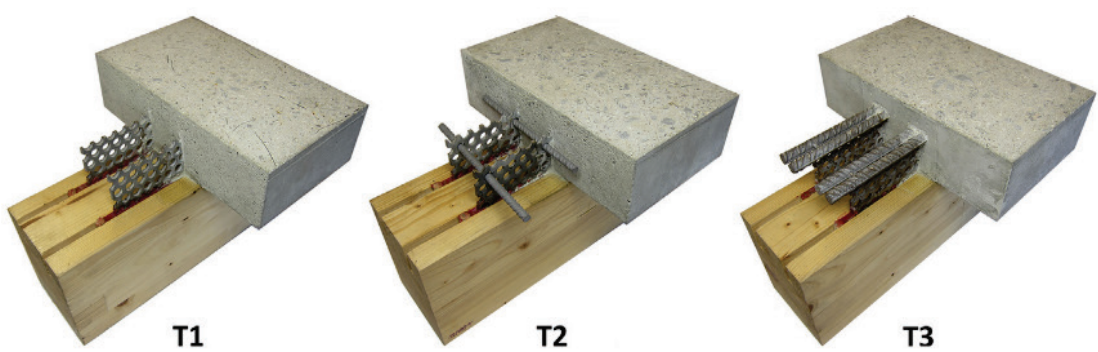

Obr. 2 Schémy drevobetónových nosníkov s použitými perforovanými ocel'ovými lištami [5]. 


\section{NUMERICKÁ ANALÝZA}

Pre uskutočnenie numerickej analýzy bol vytvorený 3D model proste podopretého drevobetónového nosníka v programe ANSYS 19 [6] (obr. 3), pričom boli využité obe osi symetrie modelu pre zrýchlenie výpočtu. Osová vzdialenost' podpier je 5,0 metra, rozmer prierezu drevenej časti (C24) je 200/100 mm, na ktorej je umiestnená betónová doska z betónu triedy C30/37 o hrúbke $100 \mathrm{~mm}$ so šírkou $650 \mathrm{~mm}$. Zat'aženie pôsobilo rovnomerne plošne na horný povrch betónovej dosky a bolo zvolené o hodnote $15 \mathrm{kN} / \mathrm{m}^{2}$. Ako typ spriahovacej lišty bol vybratý typ MCL [3] o hrúbke $5 \mathrm{~mm}$ (hrúbka je funkciou vel'kosti lišty; hodnota vyplýva zo zvolenej vel'kosti spriahovacej lišty podl'a návrhového manuálu [3]) vo vzájomnej vzdialenosti 50 milimetrov z ocele S355. Kontakt medzi lištou a dreveným prierezom bol riešený ako tuhý, medzi lištou a betónom ako frikčný s frikčným koeficientom 0,3 .

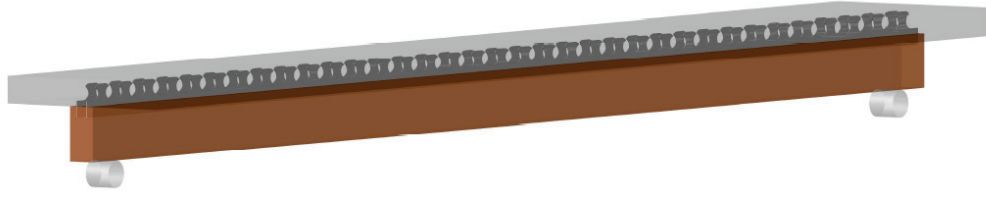

Obr. 3 3D model drevobetónového nosníka vstupujúceho do numerickej analýzy.

Analýza pozostávala z prvotnej simulácie drevobetónového prierezu bez spriahovacej lišty pre získanie referenčných výsledkov (napätia a deformácia) - kombinovaného prierezu bez účinku spriahnutia a plne spriahnutého prierezu. Materiálový model betónu a dreva bol počiatočne zvolený ako lineárny (L). Následne boli do prierezu pridané spriahovacie lišty typu MCL o hrúbke $5 \mathrm{~mm}$ (2 varianty $-\mathrm{s}$ lineárnym (L) a nelineárnym materiálovým modelom (NL)), pričom ich hrúbka postupne klesala na hodnotu 2 milimetre (modely s nelineárnou (NL) materiálnou charakteristikou ocele - skutočný diagram ocele). Pre porovnanie bol vyhodnotený aj variant s vlepenou lištou typu HBV® o hrúbke 2 milimetre.

Pre porovnanie výsledkov bol zmenený materiálový model betónu na nelineárny (Menetrey-William [7]), ako aj analyzovaný efekt po porušení dreveného prierezu na deformáciu a napätia $\mathrm{v}$ drevobetónovom nosníku vytvorením prerušenia dreveného prierezu v strede nosníka.

V závere bola vytvorená aj parametrická štúdia, kde došlo k postupnému zvyšovaniu zat’aženia na limitnú hodnotu t'ahových napätí krajných vlákien v drevenej časti prierezu (C14-C50), pričom boli analyzované napätia v lište a betóne, ako aj vplyv zat’aženia a triedy materiálu na deformáciu.

\section{VÝSLEDKY}

Výsledky pre kombinovaný prierez bez účinku spriahnutia (vzorka 1) a plne spriahnutý prierez (vzorka 2) sa nachádzajú v Tab. 1. Sú to referenčné hodnoty pre porovnanie s ostatnými analyzovanými modelmi a budú slúžit' pre interpretovanie výsledkov z ostatných simulácií.

Tab. 1 Výsledky numerických simulácií pre kombinovaný prierez bez účinku spriahnutia a plne spriahnutý prierez.

\begin{tabular}{|c|c|c|c|c|c|c|}
\hline \multirow[t]{2}{*}{ № } & Drevo & Betón & $\begin{array}{c}\text { Max. } \sigma \\
\operatorname{drevo}[\mathrm{MPa}]\end{array}$ & $\begin{array}{c}\text { Max. } \sigma^{\oplus} \\
\text { betón [MPa] }\end{array}$ & $\begin{array}{c}\text { Max. } \sigma^{\ominus} \\
\text { betón [MPa] }\end{array}$ & \multirow{2}{*}{$\begin{array}{c}\text { Max. zvislá } \\
\text { deformácia } \\
{[\mathrm{mm}]}\end{array}$} \\
\hline & \multicolumn{2}{|c|}{ Ocel' } & \multicolumn{3}{|c|}{ Max. $\sigma$ v ocel'ovej lište [MPa] } & \\
\hline 1 & $\mathrm{C} 24(\mathrm{~L})$ & C30/37 (L) & 13,21 & $\begin{array}{c}+19,9 \\
-\end{array}$ & $-19,9$ & 28,02 \\
\hline 2 & $\mathrm{C} 24(\mathrm{~L})$ & $\begin{array}{l}\mathrm{C} 30 / 37(\mathrm{~L}) \\
-\end{array}$ & 11,1 & $\begin{array}{c}+5,75 \\
-\end{array}$ & $-9,59$ & 11,1 \\
\hline
\end{tabular}

Následne bola do modelu pridaná dvojica spriahovacích líšt typu MCL o hrúbke $5 \mathrm{~mm}$, pričom model bol plne materiálovo lineárny (vzorka 3) a následne bola materiálová charakteristika ocel’ovej lišty (vzorka 4) zmenená na nelineárnu - skutočný diagram ocele S355. Vplyv tenších líšt (mimo odporúčaného intervalu uvedeného v návrhovom postupe [3]) na parametre nosníka pod zat’ažením bol analyzovaný na vzorkách 5 až 7, pričom pre porovnanie bola namodelovaná aj vzorka s osadenou lištou typu HBV® o hrúbke $2 \mathrm{~mm}$ (vzorka 8). Výsledky pre uvedené vzorky 3 až 8 sa nachádzajú v Tab. 2 . 
Tab. 2 Výsledky numerických simulácií pre spriahnutý prierez lištami typu MCL a HBV®.

\begin{tabular}{|c|c|c|c|c|c|}
\hline \multirow[t]{2}{*}{ № } & Drevo & $\begin{array}{c}\text { Max. } \sigma \\
\operatorname{drevo}[\mathrm{MPa}]\end{array}$ & $\begin{array}{c}\text { Max. } \sigma \oplus \\
\text { betón [MPa] }\end{array}$ & $\begin{array}{c}\text { Max. } \sigma \ominus \\
\text { betón [MPa] }\end{array}$ & \multirow{2}{*}{$\begin{array}{c}\text { Max. zvislá } \\
\text { deformácia } \\
{[\mathrm{mm}]}\end{array}$} \\
\hline & Ocel' & \multicolumn{3}{|c|}{ Max. $\sigma$ v ocel'ovej lište [MPa] } & \\
\hline 3 & $\begin{array}{c}\text { C24 (L) } \quad \text { C30/37 (L) } \\
\text { S355 hr.5 mm (L) }\end{array}$ & 10,62 & $\begin{array}{r}+5,67 \\
60,25\end{array}$ & $-9,85$ & 10,97 \\
\hline 4 & $\begin{array}{c}\mathrm{C} 24(\mathrm{~L}) \quad \mathrm{C} 30 / 37(\mathrm{~L}) \\
\text { S355 hr.5 mm (NL) }\end{array}$ & 9,41 & $\begin{array}{r}+4,78 \\
53,7\end{array}$ & $-9,1$ & 9,76 \\
\hline 5 & $\begin{array}{c}\mathrm{C} 24(\mathrm{~L}) \quad \mathrm{C} 30 / 37(\mathrm{~L}) \\
\mathrm{S} 355 \mathrm{hr} .4 \mathrm{~mm}(\mathrm{NL})\end{array}$ & 9,48 & $\begin{array}{r}+4,84 \\
54,42\end{array}$ & $-8,84$ & 9,84 \\
\hline 6 & $\begin{array}{c}\text { C24 (L) } \quad \text { C30/37 (L) } \\
\text { S355 hr.3 mm (NL) }\end{array}$ & 9,54 & $\begin{array}{r}+4,99 \\
54,75\end{array}$ & $-8,9$ & 9,93 \\
\hline 7 & $\begin{array}{c}\mathrm{C} 24(\mathrm{~L}) \quad \mathrm{C} 30 / 37(\mathrm{~L}) \\
\text { S355 hr.2 mm (NL) }\end{array}$ & 9,63 & $\begin{array}{c}+5,12 \\
54,96\end{array}$ & $-8,95$ & 10,05 \\
\hline 8 & $\begin{array}{c}\mathrm{C} 24(\mathrm{~L}) \quad \mathrm{C} 30 / 37(\mathrm{~L}) \\
\text { S355 HBV } ®(\mathrm{NL})\end{array}$ & 9,68 & $\begin{array}{l}+4,94 \\
221,38\end{array}$ & $-8,93$ & 10,02 \\
\hline
\end{tabular}

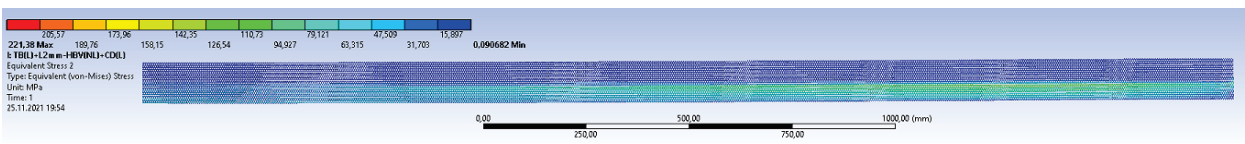

Obr. 4 Napätia v pravej polovici ocel’ovej spriahovacej lište HBV® v nosníku (vzorka 8).

Pre spresnenie výpočtu bol zmenený materiálový model betónu na nelineárny (vzorka 9), čím je možné zároveň porovnat' tento vplyv s modelom s lineárnou charakteristikou betónu (vzorka 4). Nakol'ko bola sledovaná aj situácia, ked' dôjde $\mathrm{k}$ porušeniu dreveného prierezu, bol tento prípad namodelovaný, a to prostredníctvom oslabenia prierezu, resp. jeho prerušením uprostred rozpätia, kde sa predpokladá vznik porušenia prierezu (vzorka 10). Výsledky sú uvedené v Tab. 3.

Tab. 3 Výsledky numerických simulácií pre spriahnutý prierez lištami s nelineárnou charakteristikou betónu a prerušeným dreveným nosníkom.

\begin{tabular}{|c|c|c|c|c|c|c|}
\hline \multirow[t]{2}{*}{ № } & Drevo & Betón & $\begin{array}{c}\text { Max. } \sigma \text { drevo } \\
\text { [MPa] }\end{array}$ & $\begin{array}{c}\text { Max. } \sigma \oplus \\
\text { betón [MPa] }\end{array}$ & $\begin{array}{c}\text { Max. } \sigma \ominus \\
\text { betón [MPa] }\end{array}$ & \multirow{2}{*}{$\begin{array}{c}\text { Max. zvislá } \\
\text { deformácia } \\
{[\mathrm{mm}]}\end{array}$} \\
\hline & \multicolumn{2}{|c|}{ Ocel' } & \multicolumn{3}{|c|}{ Max. $\sigma$ v ocel'ovej lište [MPa] } & \\
\hline \multirow{2}{*}{9} & $\mathrm{C} 24(\mathrm{~L})$ & $\mathrm{C} 30 / 37$ (NL) & 9,86 & $+2,89$ & $-8,17$ & \multirow{2}{*}{10,3} \\
\hline & S355 & $\mathrm{mm}(\mathrm{NL})$ & & 55 & & \\
\hline \multirow{2}{*}{10} & C24 (L) & C30/37 (NL) & 6,12 & $+2,89$ & $-26,74$ & \multirow{2}{*}{18,43} \\
\hline & S355 & $\mathrm{mm}(\mathrm{NL})$ & & 371,88 & & \\
\hline
\end{tabular}

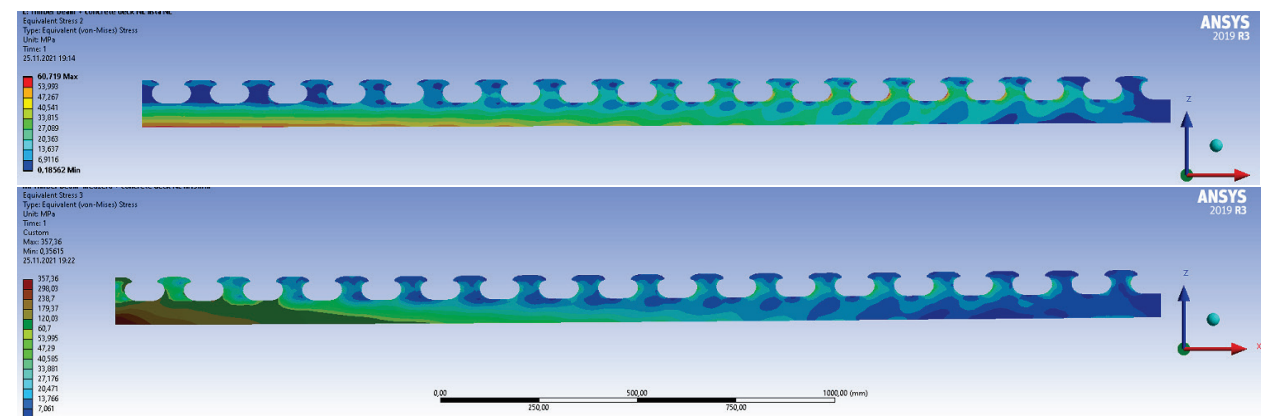

Obr. 5 Porovnanie napätia v pravej časti ocel'ovej spriahovacej lište s neprerušeným dreveným prierezom (vzorka 9; hore) a s prerušeným dreveným prierezom uprostred rozpätia, pričom tmavé oblasti predstavujú oblasti s napätiami vyššími ako v prípade vzorky s neporušeným dreveným prierezom (vzorka 10; dole). 
Na záver bola pripravená parametrická štúdia (vzorka 11-23), v ktorej sa menili materiálové parametre drevenej časti prierezu a zat’aženie tak, aby došlo k dosiahnutiu maximálneho t’ahového napätia v spodných vláknach dreveného prierezu. Sledoval sa rast napätí v celom drevobetónovom priereze, zvislá deformácia ako aj hodnota zat’aženia, pri ktorom maximálne napätie v drevenej časti nastalo. Výsledky sú uvedené v Tab. 4.

Tab. 4 Výsledky numerických simulácií pre spriahnutý prierez lištami s nelineárnou charakteristikou betónu a prerušeným dreveným nosníkom.

\begin{tabular}{|c|c|c|c|c|c|c|}
\hline № & $\begin{array}{l}\text { Betón } \\
\text { Ocel' }\end{array}$ & $\begin{array}{c}\text { Max. } \sigma \text { drevo } \\
\text { [MPa] }\end{array}$ & $\begin{array}{c}\text { Max. } \sigma^{\oplus} \text { betón } \\
{[\mathrm{MPa}]}\end{array}$ & $\begin{array}{c}\text { Max. } \sigma^{\ominus} \\
\text { betón [MPa] }\end{array}$ & $\begin{array}{c}\text { Zvislá } \\
\text { deform. } \\
\text { [mm] }\end{array}$ & $\begin{array}{c}\text { Max. } \\
\text { zat'aženie } \\
{\left[\mathbf{k N} / \mathbf{m}^{2}\right]} \\
\end{array}$ \\
\hline \multirow{2}{*}{11} & $\mathrm{C} 14(\mathrm{~L}) \quad \mathrm{C} 30 / 37(\mathrm{NL})$ & 8,0 & $+2,89$ & $-10,67$ & \multirow{2}{*}{13,06} & \multirow{2}{*}{18,7} \\
\hline & $\mathrm{S} 355 \mathrm{hr} .5 \mathrm{~mm}(\mathrm{NL})$ & & 82,9 & & & \\
\hline \multirow{2}{*}{12} & $\mathrm{C} 16(\mathrm{~L}) \quad \mathrm{C} 30 / 37(\mathrm{NL})$ & 10,0 & $+2,89$ & $-12,02$ & \multirow{2}{*}{14,35} & \multirow{2}{*}{22,5} \\
\hline & $\mathrm{S} 355 \mathrm{hr} .5 \mathrm{~mm}(\mathrm{NL})$ & & 89,65 & & & \\
\hline \multirow{2}{*}{13} & $\mathrm{C} 18(\mathrm{~L}) \quad \mathrm{C} 30 / 37(\mathrm{NL})$ & 11,0 & $+2,89$ & $-12,14$ & \multirow{2}{*}{14,14} & \multirow{2}{*}{24,0} \\
\hline & $\mathrm{S} 355 \mathrm{hr} .5 \mathrm{~mm}(\mathrm{NL})$ & & 86,2 & & & \\
\hline \multirow{2}{*}{14} & $\mathrm{C} 20(\mathrm{~L}) \quad \mathrm{C} 30 / 37(\mathrm{NL})$ & 12,0 & $+2,89$ & $-12,75$ & \multirow{2}{*}{14,7} & \multirow{2}{*}{25,9} \\
\hline & $\mathrm{S} 355 \mathrm{hr} .5 \mathrm{~mm}(\mathrm{NL})$ & & 88,4 & & & \\
\hline \multirow{2}{*}{15} & $\mathrm{C} 22(\mathrm{~L}) \quad \mathrm{C} 30 / 37(\mathrm{NL})$ & 13,0 & $+2,89$ & $-13,3$ & \multirow{2}{*}{15,12} & \multirow{2}{*}{27,75} \\
\hline & $\mathrm{S} 355 \mathrm{hr} .5 \mathrm{~mm}(\mathrm{NL})$ & & 90,2 & & & \\
\hline \multirow{2}{*}{16} & $\mathrm{C} 24(\mathrm{~L}) \quad \mathrm{C} 30 / 37(\mathrm{NL})$ & 14,0 & $+2,89$ & $-13,5$ & \multirow{2}{*}{14,98} & \multirow{2}{*}{29,3} \\
\hline & $\mathrm{S} 355 \mathrm{hr} .5 \mathrm{~mm}(\mathrm{NL})$ & & 87,3 & & & \\
\hline \multirow{2}{*}{17} & $\mathrm{C} 27(\mathrm{~L}) \quad \mathrm{C} 30 / 37(\mathrm{NL})$ & 16,0 & $+2,89$ & $-13,95$ & \multirow{2}{*}{16,39} & \multirow{2}{*}{33,2} \\
\hline & S355 hr.5 mm (NL) & & 95,0 & & & \\
\hline \multirow{2}{*}{18} & $\mathrm{C} 30(\mathrm{~L}) \quad \mathrm{C} 30 / 37(\mathrm{NL})$ & 18,0 & $+2,89$ & $-15,25$ & \multirow{2}{*}{17,68} & \multirow{2}{*}{37,0} \\
\hline & S355 hr.5 mm (NL) & & 100,9 & & & \\
\hline \multirow{2}{*}{19} & $\mathrm{C} 35(\mathrm{~L}) \quad \mathrm{C} 30 / 37(\mathrm{NL})$ & 21,0 & $+2,89$ & $-16,7$ & \multirow{2}{*}{19,18} & \multirow{2}{*}{42,5} \\
\hline & S355 hr.5 mm (NL) & & 107,5 & & & \\
\hline \multirow{2}{*}{20} & $\mathrm{C} 40(\mathrm{~L}) \quad \mathrm{C} 30 / 37(\mathrm{NL})$ & 24,0 & $+2,89$ & $-18,15$ & \multirow{2}{*}{20,45} & \multirow{2}{*}{47,8} \\
\hline & S355 hr.5 mm (NL) & & 111,9 & & & \\
\hline \multirow{2}{*}{21} & $\mathrm{C} 45(\mathrm{~L}) \quad \mathrm{C} 30 / 37(\mathrm{NL})$ & 27,0 & $+2,89$ & $-19,45$ & \multirow{2}{*}{21,64} & \multirow{2}{*}{53,0} \\
\hline & S355 hr.5 mm (NL) & & 115,5 & & & \\
\hline 22 & $\mathrm{C} 50(\mathrm{~L}) \quad \mathrm{C} 30 / 37(\mathrm{NL})$ & 30,0 & $+2,89$ & $-20,7$ & 2273 & 58.1 \\
\hline & $\mathrm{S} 355 \mathrm{hr} .5 \mathrm{~mm}(\mathrm{NL})$ & & 118,3 & & 22,13 & 58,1 \\
\hline
\end{tabular}

\section{DISKUSIA}

Numerickými simuláciami sa potvrdil predpokladaný priaznivý vplyv spriahnutia drevenej a betónovej časti prierezu na hodnotu deformácie a napätí v skúmanom nosníku (vzorka 1 a 2). Pridaním spriahovacích líšt do modelu sa tiež potvrdila skutočnost', že pridaním spriahovacích líšt dôjde v malej miere k zmenšeniu napätí v priereze, ako aj deformácie (vzorka 3). Spresnením materiálového modelu ocel'ovej lišty na nelineárny došlo v dôsledku spresnenia výpočtu k d’alšej redukcii napätí a deformácie (vzorka 4).

V prípade zmenšovania hrúbky spriahovacej lišty nedochádza k výraznému vzrastu hodnôt napätí a deformácie nosníka, čo je priaznivé pre úsporu materiálu, ako aj jednoduchšiu manipuláciu a montáž samotnej spriahovacej lišty (vzorky 5 až 7). Prekvapivým záverom je porovnanie vzoriek nosníka so spriahovacou lištou typu MCL hr. 2 mm (vzorka 7) a lištou HBV® (vzorka 8) - napätia v drevenej a betónovej časti prierezu, rovnako ako deformácia boli takmer totožné, no v prípade lišty typu HBV® sú napätia v lište výrazne vyššie, avšak vyššie hodnoty napätí sa nachádzajú najmä v časti lišty zapustenej v drevenej časti prierezu (obr.4).

Pre spresnenie výsledkov (najmä kvôli vyšším hodnotám t'ahových napätí v betónovej časti prierezu) došlo k zmene materiálového modelu betónu na nelineárny (vzorka 9), čo sa prejavilo malým zväčšením deformácie (v porovnaní so vzorkou 4), no najmä korekcie napätí v betónovej časti prierezu. Nakol'ko rozhodujúcou čast’ou prierezu z hl'adiska odolnosti je na základe predchádzajúcich simulácií únosnost' drevenej čast', predpokladá sa, že primárne dôjde k porušeniu dreveného prierezu v strede rozpätia. Aby sa zachytil účinok porušenia drevenej časti, bol drevený prierez v strede nosníka oslabený vynechaním (vzorka 10). Došlo k výrazným napätostným zmenám v priereze - hodnota tlakových napätí v betóne sa strojnásobila, výrazne sa zvýšilo a čiastočne aj 
redistribuovalo napätie v ocel’ovej lište (obr.5). Maximálne napätie v drevenej časti prierezu sa nachádza približne v tretinách nosníka. Hodnota deformácie sa takmer zdvojnásobila, no stále dosahuje približne 74 percent limitnej hodnoty priehybu, čo je stále akceptovatel'ná hodnota.

V záverečnej parametrickej štúdii (vzorka 11 až 22) došlo k analýze vplyvu zvyšovania zat'aženia na limitnú hodnotu t’ahových napätí v drevenej časti drevobetónového nosníka (podl’a EN 338 [8]). Napriek násobnému zväčšovaniu napätí v drevenej časti, nárast deformácie bol podstatne nižší, podobne ako nárast napätí vo zvyšnom priereze .Z výsledkov je možné interpretovat' skutočnost', že všetky skúmané vzorky v rámci parametrickej štúdie (vzorka 11 až 22) splnili podmienku limitného priehybu (1/200 rozpätia) o hodnote $25 \mathrm{~mm}$.

Záverom je možné tiež konštatovat', že spresnením materiálových modelov došlo k redukcii napätostných parametrov, ako aj deformácie. Vzhl'adom na náročnost' plastického modelu dreva sa v tejto analýze uvažovalo len s lineárnym materiálovým modelom. V porovnaní s lištou typu HBV® je lišta typu MCL podstatne menej namáhaná a k jej efektívnemu využitiu dochádza až v momente prípadného porušenia dreveného prierezu.

\section{ZÁVER}

Analýzou sa potvrdil potenciál využitia spriahovacích líšt bežne používaných v prípade ocel'obetónových konštrukcií, pričom ich primárny účel, a to prenos pozdížnych šmykových síl medzi drevenou a betónovou čast'ou prierezu, plnia spol’ahlivo a účinne. Ich analýza v prostredí numerických simulácii je spol'ahlivá aj v prípade použitia lineárnych materiálových modelov, čo rozširuje možnosti výskumu a analýzy aj do iných programov. Potvrdil sa predpoklad, že je možné modifikovat' odporúčané geometrické intervaly lišty, a to najmä pomer hrúbky a výšky - tenšie lišty fungujú rovnako spol'ahlivo bez vzniku miest s koncentráciami napätí, podobne ako lišty HBV®, ktoré sa používajú v drevobetónových konštrukciách. Taktiež sa analyzoval aj stav pri porušení drevenej časti prierezu s ciel'om podrobného zistenia redistribúcie napätí v priereze.

Parametrickou štúdiou sa potvrdil výrazný vplyv materiálových parametrov drevenej časti prierezu na maximálnu možnú zat'ažitel'nost', ako aj deformáciu. Rast napätí v spriahovacej lište bol nevýrazný a ich hodnota zd’aleka nedosahovala medzu klzu ocele, čo predstavuje priestor na ich prípadnú optimalizáciu. Záverom je možné konštatovat', že spriahovacie lišty vlepované do dreveného prierezu je možné považovat' za bezpečnú a spol'ahlivú alternatívu $\mathrm{k}$ iných spriahovacím prostriedkom používaných v drevobetónových konštrukciách. Je však potrebný podrobnejší výskum takýchto konštrukcií, ktorý by komplexne pokryl celú problematiku s ciel'om vytvorit' spol'ahlivý návrhový postup na zhotovovanie takýchto konštrukcií.

\section{Použité zdroje}

[1] Springer, J., Reuke, H., Wolters, K., \& Kopp, M. (2018). Besonderheiten der Stahlverbundkonstruktion des Parkhauses Coulinstraße in Wiesbaden. Stahlbau, 87(7), 695-703. https://doi.org/10.1002/stab.201810625

[2] TiComTec GmbH. (2014). Tragwerke in Holz-Beton-Verbundbauweise mit eingeklebten HBV ® Schubverbindern.

[3] Deutsches Institut für Bautechnik. (2018). Allgemeine bauaufsichtliche Zulassung Z-26.4-56 Stahlverbundträger mit Verbunddübelleisten in Klothoiden- und Puzzleform.

[4] Deutsches Institut für Bautechnik. (2020). Allgemeine bauaufsichtliche Zulassung Z-9.1-557 - HBVSchubverbinder aus Streckmetall und vorgefertigte Bauteile mit eingeklebten; HBV-Schubverbindern für ein Holz-Beton-Verbundsystem.

[5] Suárez-Riestra, F., Estévez-Cimadevila, J., Martín-Gutierrez, E., \& Otero-Chans, D. (2019). Perforated shear + reinforcement bar connectors in a timber-concrete composite solution. Analytical and numerical approach. Composites Part B: Engineering, 156, 138-147. https://doi.org/10.1016/j.compositesb.2018.08.074

[6] Software ANSYS 2019: User's Manual, Available on the internet: <https://ansyshelp.ansys.com>

[7] DYNARDO GmbH. (2013). multiPlas Release 4.1.8 for ANSYS 14.5 - Elasto-plastic material models for ANSYS General multisurface plasticity - User's Manual.

[8] Európsky výbor pre normalizáciu. (2016). STN EN 338: Konštrukčné drevo. Pevnostné triedy. 